\title{
PENGEMBANGAN APLIKASI MONITORING KELUHAN PELANGGAN MYREPUBLIC PALEMBANG
}

\author{
Nyimas Sopiah ${ }^{1}$, Bayu Sutopo ${ }^{2}$ \\ Universitas Bina Darma \\ Jalan Jenderal Ahmad Yani No.3 Palembang \\ Sur-el : nyimas.sopiah@binadarma.ac.id ${ }^{1}$
}

\begin{abstract}
Customer complaints are an indicator, symptom, and sign of dissatisfaction with the company's products or services. This has resulted in many customers feeling dissatisfied because the response and complaint handling process takes a long time. This long process is due to the fact that the Palembang City Myrepublic branch office does not yet have a separate customer complaint service system, so handling all complaint reports is still delegated to the Jakarta Head Office. The solution to overcome these problems is to build a monitoring application that can manage the handling of complaints from Myrepublic customers in Palembang City. So that customers can file complaints directly without having to go through Myrepublic Jakarta head office. This will facilitate and speed up the processing time for handling complaints. In addition, customers can also carry out monitoring or supervision for repair cases that take more than one day. Thus, customers will feel comfortable and at home to continue using Myrepublic services. The system is built using the Web Engineering method and the PHP programming language, and uses MYSQL as the database programming language.
\end{abstract}

Keywords: Application, Web Engineering, Monitoring customer complaints

\begin{abstract}
Abstrak : Keluhan pelanggan merupakan salah satu indikator, gejala, dan tanda adanya ketidakpuasan atas produk atau layanan perusahaan. Hal ini mengakibatkan banyak pelanggan yang merasa kurang puas karena proses tanggapan dan penanganan keluhan memakan waktu yang cukup lama. Proses yang lama ini disebabkan oleh karena kantor cabang Myrepublic Kota Palembang belum memiliki sistem layanan keluhan pelanggan secara tersendiri, sehingga untuk menangani semua laporan keluhan masih di limpahkan ke Kantor Pusat Jakarta. Solusi dalam mengatasi permasalahan tersebut, dengan membangun sebuah aplikasi monitoring yang dapat mengelola penanganan keluhan pelanggan Myrepublic Kota Palembang. Sehingga pelanggan dapat mengajukan laporan keluhan secara langsung tanpa harus melalui kantor pusat Myrepublic Jakarta. Dengan demikian akan memudahkan dan mempercepat waktu proses penanganan keluhan. Selain itu, pelanggan juga dapat melakukan monitoring atau pengawasan untuk kasus perbaikan yang memakan waktu yang lebih dari satu hari. Dengan demikian pelanggan akan merasa nyaman dan betah untuk tetap menggunakan layanan Myrepublic. Sistem yang dibangun dengan menggunakan metode Web Engineering dan bahasa pemrograman PHP, serta menggunakan MySQL sebagai bahasa pemrograman database.
\end{abstract}

Kata kunci:Aplikasi, Web Engineering, Monitoring Keluhan Pelanggan

\section{PENDAHULUAN}

Myrepublic adalah sebuah perusahaan telekomunikasi dengan fokus usaha pada penyediaan jasa layanan internet dan TV Kabel yang melayani pelanggan baik perorangan maupun korporasi. Perusahaan ini beroperasi berpusat di Jakarta dan memiliki kantor-kantor cabang di berbagai wilayah kota di Indonesia khususnya Kota Palembang. Myrepublic sendiri berdiri sejak tahun 2011 dan telah melayani jutaan pelanggan di seluruh Indonesia. Akses internet yang cepat dan stabil adalah hal utama yang menarik minat pelanggan untuk menggunakan layanan Myrepublic. Komplain atau keluhan adalah sebagai akibat kebalikan 
dari kepuasan pelanggan. Keluhan pelanggan adalah salah satu indikator, gejala, dan tanda adanya ketidakpuasan atas produk atau layanan perusahaan [1]. Namun dalam hal pelayanan keluhan dari pelanggan, Myrepublic bergantung dengan operator pusat di Jakarta. Hal ini sangat mempengaruhi proses tanggapan dan penanganan terhadap keluhan dari pelanggan. Pelanggan harus membuat laporan keluhan ke kantor pusat Jakarta terlebih dahulu, kemudian pihak kantor pusat akan menghubungi kantor cabang di Palembang. Setelah itu kantor cabang akan menghubungi petugas lapangan yang kemudian baru lah petugas tersebut datang kerumah pelanggan untuk melakukan pengecekan kerusakan atau gangguan yang terjadi.

Hal ini mengakibatkan banyak pelanggan yang merasa kurang puas karena proses tanggapan dan penanganan keluhan memakan waktu yang cukup lama. Alasan Kantor Pusat Myrepublic Jakarta masih menangani semua laporan keluhan adalah dikarenakan kantor cabang Myrepublic Kota Palembang belum memiliki sistem layanan keluhan pelanggan secara tersendiri, sehingga untuk menangani semua laporan keluhan masih dilimpahkan ke Kantor Pusat Jakarta.

Untuk kota Palembang dengan jumlah karyawan tiga puluh tiga orang, dirasakan sudah cukup memadai dan mampu untuk menangani sendiri laporan keluhan dari masyarakat kota Palembang dan sekitarnya. Maka dari itu perlu dibangun sebuah suatu aplikasi monitoring yang dapat mengelola penanganan keluhan pelanggan Myrepublic Kota Palembang sehingga pelanggan dapat mengajukan laporan keluhan secara langsung dan cepat melalui sistem informasi monitoring ke kantor cabang Palembang, tanpa harus melalui kantor pusat Myrepublic Jakarta. Hal ini akan sangat memudahkan dan mempercepat waktu proses penanganan keluhan. Selain itu, pelanggan juga dapat melakukan monitoring atau pengawasan untuk kasus perbaikan yang memakan waktu yang lebih dari satu hari. Sehingga dengan demikian pelanggan akan merasa nyaman dan betah untuk tetap menggunakan layanan Myrepublic, karena keluhan yang diajukan dengan cepat dapat ditanggapi dan ditangani. Sistem ini dibangun dengan menggunakan metode Web Engineering dan bahasa pemrograman PHP, serta menggunakan MySQL sebagai bahasa pemrograman database.

\section{METODOLOGI PENELITIAN}

Metode pengembangan aplikasi yang digunakan dalam penelitian ini adalah metode web engineering. Tahapan kerjanya adalah komunikasi, analisis kebutuhan, desain, implementasi, dan pengujian [2]. Alat bantu yang digunakan untuk merancang menggunakan metode berorietasi objek yaitu dengan membuat use case diagram dan activity diagram. Sedangkan untuk hubungan antar tabel menggunakan entity Relationship Diagram (ERD) [3].

Beberapa penelitian yang berkaitan dengan keluhan pelanggan telah dilakukan sebelumnya. Diantaranya adalah penanganan keluhan pelanggan berbasis Web E-RCM [4] 
pengaduan pelanggan menggunakan framework codeigniter [5], monitoring pengaduan dan keluhan pelanggan berbasis web [6], penangan keluhan pelanggan di Rumah Sakit [7].

\section{HASIL DAN PEMBAHASAN}

\subsection{Komunikasi}

Pada tahap ini, peneliti melakukan komunikasi dengan pihak MyRepublic Palembang untuk mendapatkan informasi yang berkaitan dengan penelitian. Sekaligus untuk mengetahui kendala apa saja yang dialami, serta proses pengajuan dan penanganan keluhan pelanggan.

Komunikasi ini dilakukan kepihak MyRepublic yang bertanggung jawab dalam proses ini bagian administrasi, bagian teknisi dan beberapa pelanggan MyRepublic Palembang, Komunikasi yang dilakukan untuk mengetahui proses dan system yang sedang berjalan terkait Keluhan dan penanganannya. Sistem yang digunakan dan alus proses keluhan dan penanganannya menjadi point penting dalam tahap komunikasi ini.

Adapun alur proses pengajuan keluhan pelanggan pada MyRepublic adalah sebagai berikut:

1) Pelanggan menghubungi Kantor Pusat di Jakarta.

2) Kantor Pusat akan menerima dan mencatat keluhan pelanggan.

3) Kantor Pusat kemudian melakukan pengecekan jaringan internet pelanggan.

4) Kantor pusat kemudian menghubungi Kantor Cabang Palembang perihal keluhan dan hasil pengecekan jaringan pelanggan tadi.

5) Kantor Cabang akan mencari dan menetukan teknisi untuk datang ke rumah pelanggan.

6) Teknisi akan di berikan informasi terkait keluhan dan permasalahan yang terjadi

7) Teknisi melakukan pengecekan dan perbaikan seusai dengan kerusakan.

8) Teknisi memberikan laporan kepada kantor cabang perihal kerusakan dan perbaikan yang telah dilakukan.

9) Kantor cabang akan memberikan informasi terkait hasil perbaikan teknisi ke kantor pusat.

10) Kantor pusat kemudian mencatat hasil perbaikan teknisi.

Dari alur proses sistem pengajuan keluhan yang sedang berjalan, ditemukan bahwa permasalahan yang dihadapi adalah lamanya proses pengajuan hingga ditanggapi oleh admin cabang palembang. Hal ini dikarenakan pelanggan harus melakukan panggilan telepon ke kantor pusat di Jakarta sehingga keluhan pelanggan tidak dapat langsung diterima oleh kantor cabang Palembang yang mengakibatkan proses tanggapan atau perbaikan menjadi lama.

\subsection{Analisis Kebutuhan}

Dari data-data yang diperoleh sebelumnya, peneliti melakukan analisa terhadap permasalahan serta kebutuhan apa saja yang dibutuhkan oleh sistem agar dapat membantu dalam proses pengajuan dan pengelolaan data keluhan pelanggan. Adapun kebutuhan yang diperlukan dalam penelitian ini yaitu Kebutuhan Fungsional dan Kebutuhan Nonfungsional. 
Kebutuhan Fungsional adalah kebutuhan yang berisi proses-proses dan layanan apa saja yang nantinya harus disediakan oleh sistem, mencakup bagaimana sistem harus bereaksi pada input tertentu dan bagaimana perilaku sistem pada situasi tertentu. Berdasarkan pengamatan yang dilakukan, peneliti menganalisa apa yang menjadi kebutuhan dalam sistem saat ini, adapun kebutuhan pengguna dalam perancangan ini antara lain :

1) Membutuhkan sistem yang dapat membantu memudahkan pelanggan dalam mengajukan keluhan secara lebih cepat serta membantu pelanggan dalam melakukan monitoring keluhan.

2) Membutuhkan sistem yang dapat membantu admin cabang Palembang dalam mengelola keluhan pelanggan secara langsung tanpa harus melalui sistem perwakilan di Kantor Pusat.

3) Membutuhkan sistem yang dapat menampung semua data dan terintegrasi sebagai satu kesatuan sehingga mempermudah dalam proses pembuatan laporan.

Dalam hal ini kebutuhan nonfungsional berupa perangkat keras dan perangkat lunak yang digunakan dalam membangun sistem, antara lain: Laptop Lenovo Legion intel CORE i7, Adobe Dreamweaver CS.5 (sebagai editor pemrograman), Xampp (sebagai server localhost), MySQL (sebagai database server), Microsoft Word 2013, contoh data keluhan pelanggan.

Berdasarkan analisa sistem yang diuraikan sebelumnya, usulan pemecahan masalah yang disarankan adalah mengembangkan Aplikasi Monitoring Penanganan Keluhan Pelanggan Pada Myrepublic Palembang.

\subsection{Desain}

Use case diagram merupakan pemodelan untuk kelakuan (behavior) sistem informasi yang akan dibuat. Use case digunakan untuk mengetahui fungsi apa saja yang ada di dalam sistem informasi dan siapa saja yang berhak menggunakan fungsi-fungsi tersebut.

Pada gambar 1 digambarkan mengenai use case dari sistem yang dibuat dimana terdapat 4 (empat) actor yaitu pelanggan, admin, teknisi dan pimpinan. Gambar tersebut merupakan interaksi antara pelanggan, admin, teknisi dan pimpinan dengan sistem yang dirancang dimana pelanggan memiliki akses untuk melakukan input keluhan serta input saran. Aktor pelanggan memiliki akses untuk melakukan input keluhan serta input saran. Aktor admin kemudian akan melihat dan mengelola daftar keluhan pelanggan. Selanjutnya teknisi akan menginput status perbaikan dan pimpinan selanjutnya dapat mengakses laporan keluhan pelanggan secara periodik. 


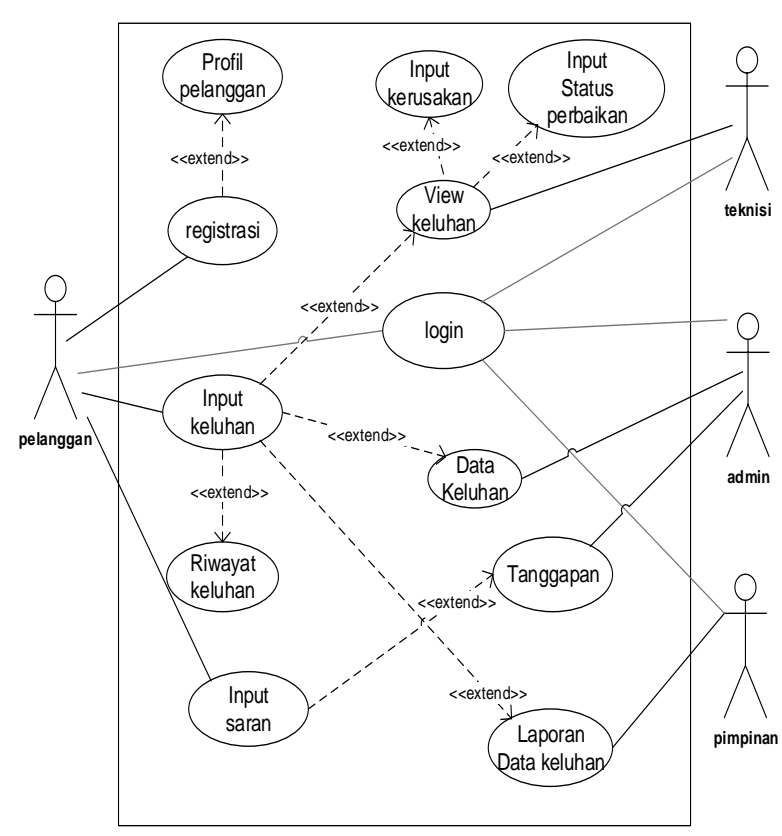

Gambar 1. Use Case Diagram

Gambar 2 menunjukkan Entity Relationship Diagram (ERD). ERD merupakan keterhubungan dari tabel-tabel pada aplikasi yang dibuat. Di mana terdiri dari 6 tabel yaitu teknisi, keluhan, kategori, saran, pelanggan dan chat.

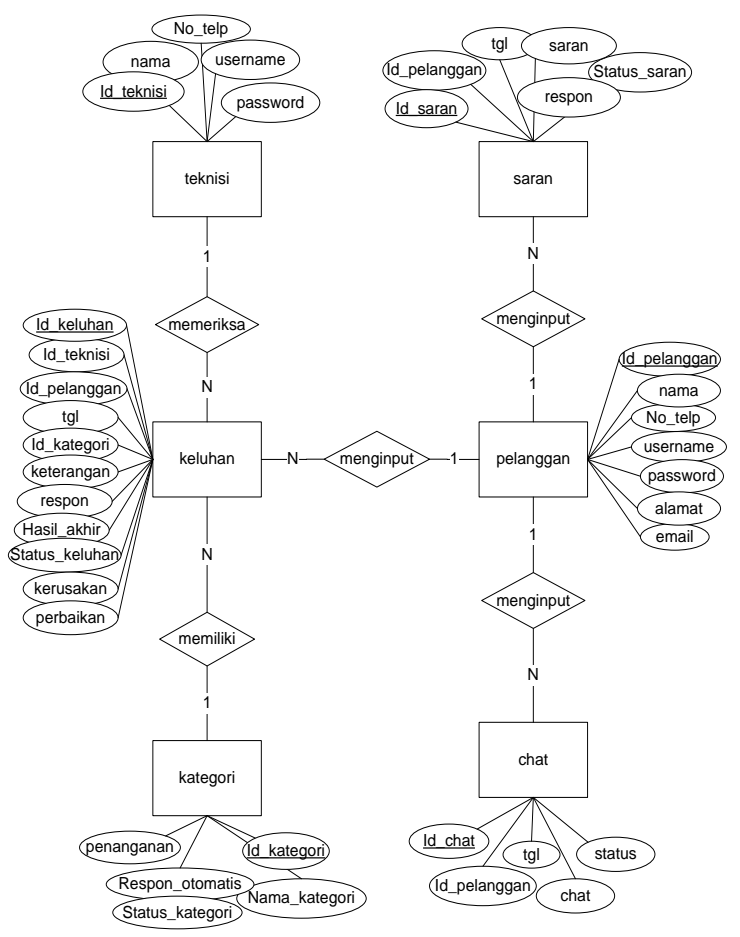

Gambar 2. Entity Relationship Diagram

\subsection{Implementasi}

Setelah melakukan analisis dan desain, kemudian tahapan selanjutnya adalah mengimplementasikan hasil perancangan kedalam bentuk web dengan menggunakan perangkat lunak Adobe Dreamweaver CS 5 sebagai PHP editor serta MySQL sebagai perangkat database.

Fitur menu yang telah dibuat adalah Form Home (merupakan menu awal saat pengguna membuka sistem. Dalam Menu Home ini, terdapat menu untuk mengajukan keluhan dan form pencarian keluhan), Form Login (merupakan menu yang digunakan untuk akses masuk ke menu admin, pelanggan dan pimpinan. Menu Admin terdiri dari beberapa menu yaitu home, Kelola Kategori, Daftar Keluhan, Daftar Keluhan Diproses, Daftar Keluhan Selesai Diproses, Daftar Teknisi, Daftar Pelanggan, Saran Pelanggan, Chat dan Logout. Form Pelanggan, terdiri dari beberapa menu Home, Input Keluhan, Riwayat Keluhan, Saran dan Kritik, Profil, Chat dan Logout. Form Pimpinan terdapat dua menu yaitu menu grafik dan laporan

Sebelum pelanggan dapat memasukkan keluhannya, maka pelanggan diharuskan untuk registrasi terlebih dahulu, seperti pada gambar 3 .

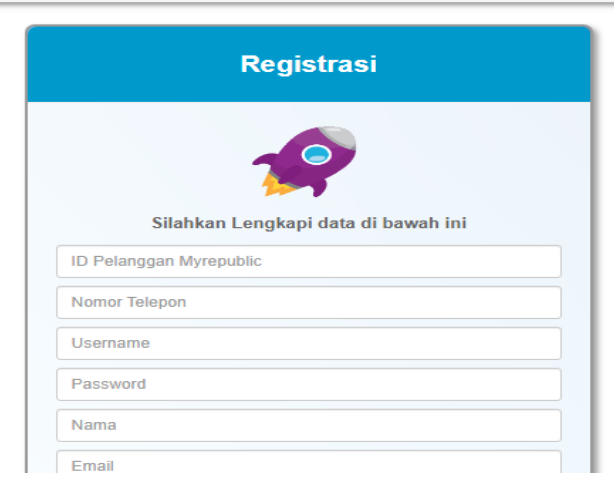

Gambar 3. Registrasi Pelanggan 
Hasil dari penelitian ini adalah menghasil aplikasi monitoring keluhan pelanggan, dimana tampilan keluhan dapat dilihat pada gambar 4.

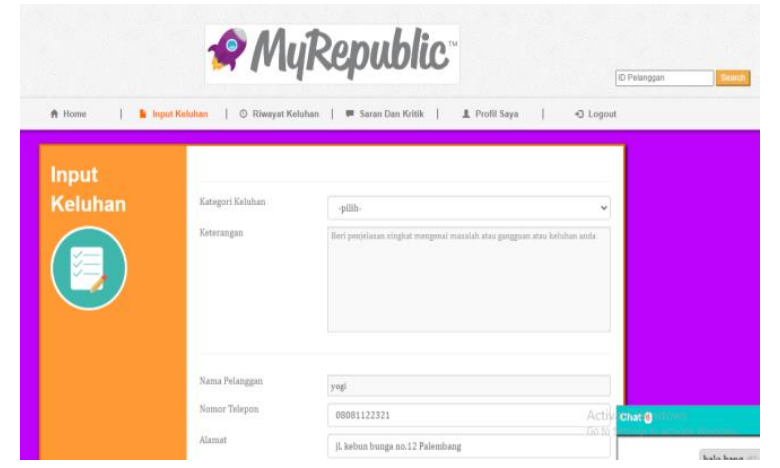

Gambar 4. Tampilan Keluhan Pelanggan

Pelanggan dapat melihat semua riwayat keluhan yang pernah dilakukan sebelumnya. Serta dapat melihat status keluhannya apakah sedang diproses atau sudah selesai diproses. Dapat dilihat pada gambar 5.

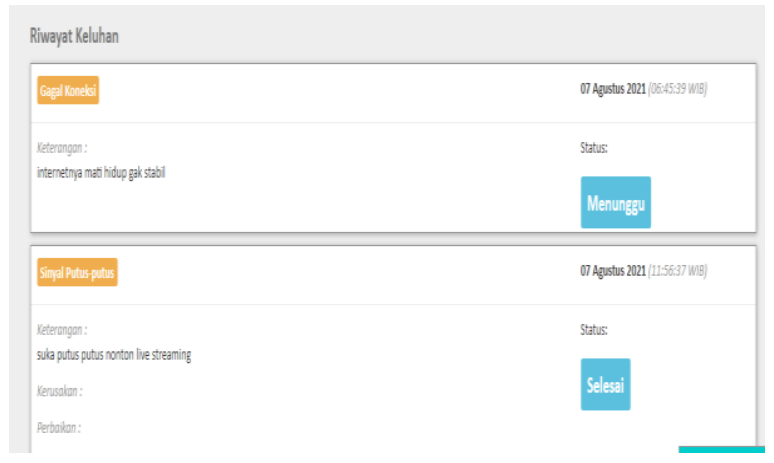

\section{Gambar 5. Riwayat Keluhan Pelanggan}

Setelah pelanggan tersebut memasukkan apa saja keluhannya, kemudian dimonitoring oleh admin dan pelanggan sendiri, sehingga pelanggan bisa apa saja tanggal pihak Myrefublic menganggapi keluhan mereka. Gambar 6 menunjukkan grafik dari tiap bulan terhadap keluhan pelanggan yang telah masuk ke aplikasi.

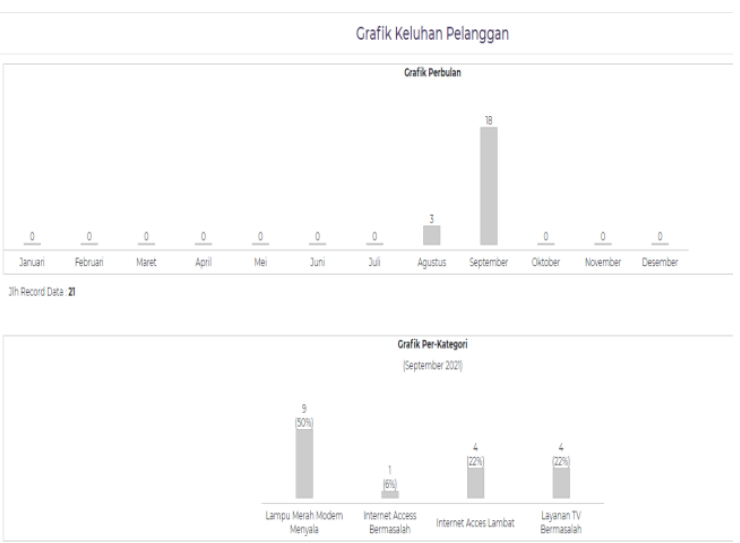

\section{Gambar 6. Grafik Keluhan Pelanggan}

Setelah keluhan sudah dimasukkan datanya oleh pelanggan ke website, maka Pihak myrepublic dapat melakukan pemrosesan dari data yang telah dimasukkan tadi. Contoh tampilannya adalah dilihat pada gambar 7 .

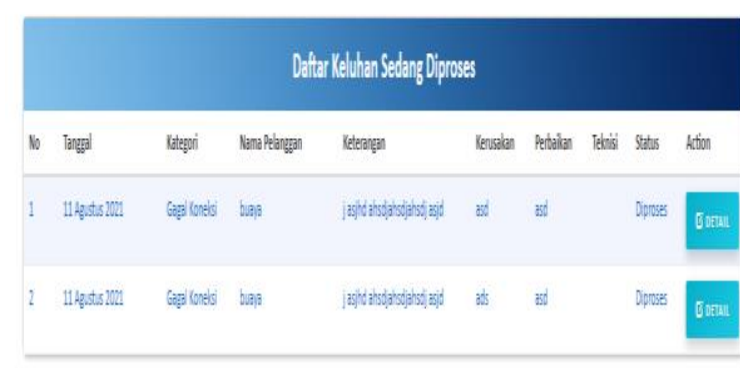

\section{Gambar 7. Daftar Keluhan yang Sedang Diproses}

Jika proses telah selesai dilakukan, maka berikut merupakan gambar detail terkait keluhan pelanggan setelah diproses pada gambar 8 .

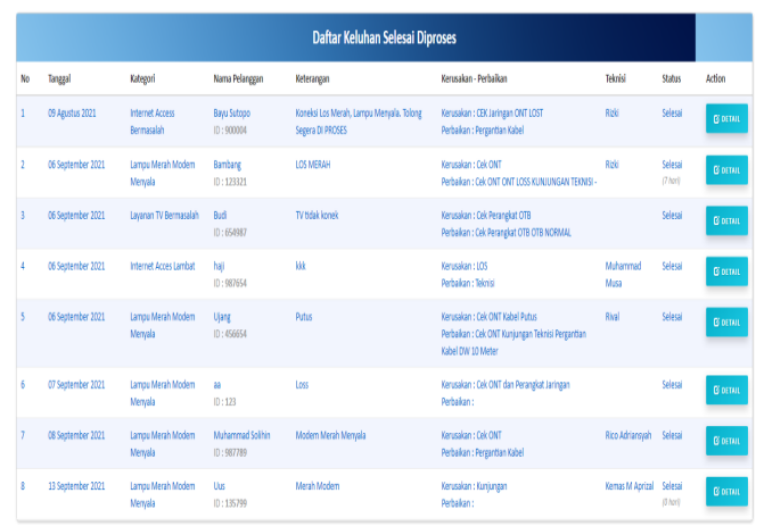

Gambar 8. Daftar Keluhan Pelanggn Selesai Diproses 
Pihak myrepublic juga bisa mengelola smeua keluhan dengan melihat laporan yang telah masuk, seperti ditunjukkan pada gambar 9 berikut.

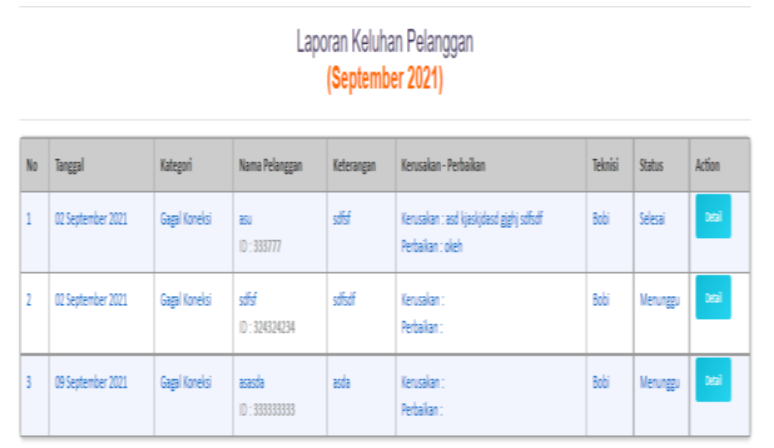

Gambar 9. Laporan Keluhan Pelanggan

\subsection{Pengujian}

Setelah membangun aplikasi monitoring penanganan keluhan pelanggan pada Myrepublic Palembang, tahap selanjutnya yaitu adalah melakukan pengujian terhadap fungsi dan kinerja sistem tersebut. Pengujian dilakukan dengan menggunakan metode blackbox testing, ini merupakan suatu pengujian yang terfokus pada persyaratan fungsionalitas dari sistem tersebut. Dengan demikian dapat diperoleh serangkaian kondisi masukan yang semuanya menggunakan persyaratan fungsional. Semua hasil pengujian telah diujicoba dan semua menu dan tampilan dapat berjalan sesuai dengan yang diinginkan.

\section{KESIMPULAN}

Berdasarkan penelitian yang telah dilakukan dan hasil pembahasan yang telah diuraikan pada beberapa bab sebelumnya, maka dapat ditarik kesimpulan bahwa Aplikasi Monitoring Penanganan Keluhan Pelanggan dapat memberikan kemudahan dalam pengelolaan data keluhan yang ada, dan memonitor setiap keluhan. Kemudian Sistem yang telah dibangun dapat membantu pelanggan untuk dapat langsung mengajukan keluhan secara langsung tanpa harus melalui kantor pusat Jakarta.Sistem yang dibangun juga dapat membantu pihak Myrepublic dalam menanggapi dan menangani langsung keluhan dari pelanggan.

\section{DAFTAR PUSTAKA}

[1] Kaihatu, T. S., Daengs, A., \& Indrianto, A. T., Manajemen Komplain. Yogyakarta: CV. Andi Offset, 2015.

[2] R. Pressman, Rekayasa Perangkat Lunak, Yogyakarta: Andi, 2002.

[3] Fathansyah, Buku Teks Komputer Basis Data, Bandung: Informatika, 2007.

[4] Rachman Hidayat dan Lona Listianingsih, "Peracangan Sistem Keluhan Pelanggan Berbasis Web E-RCM dengan Model Waterfall pada PT Unggul Cipata Teknologi,“ Jurnal Sinkron, vol 2 no 2, April 2018, pp. 112-118.

[5] Casro, Yuli Purwati, Gustin Setyaningsih, Adam Prayogo Kuncoro, "Rancangan Bangun Aplikasi Pengaduan Pelanggan Berbasis Web Menggunakan Framework Codeigniter di Indotechno Purwokerto," Jurnal Sains dan Informatika vol.6 no.2 November 2020, pp. 166-174.

[6] Budi Setiadi, Johan Wahyudi, "Aplikasi Monitoring Pengaduan dan Keluhan Pelanggan pada PT. PLN (Persero) Area Banjarmasin Berbasis Web," Jurnal Technologia, vol.11 no.4, Oktober 2020, pp. 234-239.

[7] Dewa Putu Yudhi Ardiana, I Made Shaja Dwiputra, "Sistem Informasi Penanganan Keluhan Pelanggan di Rumah Sakit Umum Surya Hushada Denpasar Berbasis Web, Jurnal Matrik, vol.18 no.2, Mei 2019, pp. 257-267. 